\title{
STRUKTUR KOMUNITAS ZOOPLANKTON DI PERAIRAN KOEONO, KECAMATAN PALANGGA SELATAN, KABUPATEN KONAWE
}

\section{Structure Community Of Zooplankton In Koeono, South of Palangga Sub District, Konawe Regency}

\author{
Anita $^{1 *}$, Wa Nurgayah ${ }^{2}$, Rahmadani $^{2}$ \\ 1,2 Program Studi Ilmu Kelautan, Fakultas Perikanan dan Ilmu Kelautan, Universitas Halu Oleo \\ JL. H.E.A Mokodompit Kampus Hijau Bumi Tridharma Anduonohu Kendari 93232 \\ *E-mail: anita.aurilia@gmail.com
}

\begin{abstract}
Abstrak
Zooplankton berperan sebagai konsumen tingkat satu yang menghubungkan fitoplankton dengan organisme tingkat tinggi. Zooplankton dapat menggambarkan keadaan suatu perairan maupun ketersediaan makanan untuk menunjang kehidupan biota. Tujuan dari penelitian ini adalah untuk mengetahui struktur komunitas dan kelimpahan zooplankton di Perairan Koeono. Penelitian ini dilakukan pada bulan Februari-Desember 2019. Penelitian ini terbagi atas 3 stasiun dengan 3 kedalaman yang berbeda yaitu $0,5 \mathrm{~m}, 5 \mathrm{~m}$ dan $10 \mathrm{~m}$. Pengambilan sampel dilakukan pada pagi hari dan sore hari. Hasil penelitian menunjukkan zooplankton yang ditemukan sebanyak 16 genera dari 5 kelas kelompok zooplankton adalah dari kelas crustacea (5 genera), kelas Maxillopoda (3 genera), kelas hexanauplia terdiri dari (4 genera), kelas cilliatea (2 genera) dan kelas olighotrichea (2 genera). Nilai indeks keanekaragaman (H') tergolong sedang, sedangkan nilai indeks keseragaman (E') tergolong seimbang. Nilai indeks dominansi (D) tergolong sedang, dimana tidak ada spesies yang mendominasi. Kelimpahan zooplankton tertinggi terdapat pada pengambilan sore hari yaitu 176 ind./L dan terendah pada pengambilan pagi hari yaitu 52 ind./L.
\end{abstract}

Kata Kunci: Koeono, Perairan, Strukrur Komunitas, Zooplankton.

\begin{abstract}
Abstrak
Zooplankton acts as one level consumer who connects phytoplankton with high-level organisms. Zooplankton can depict the state of a water or food availability to support the life of biota. The aim of the study was to knowing the community structure and abundance of zooplankton in the Koeono waters. The research was conducted in February-December 2019. The research is divided into 3 stations with 3 different depths of $0.5 \mathrm{~m}, 5 \mathrm{~m}$ and $10 \mathrm{~m}$. Sampling is done in the morning and in the afternoon. The results showed that zooplankton were found as many 16 genera from 5 classes of zooplankton group namely from the crustacean (5 genera), Maxillopoda class ( 3 genera), hexanauplia class (4 genera), cilliatea class ( 2 genera) dan olighotrichea class (2 genera). The value of diversity index $\left(\mathrm{H}^{\prime}\right)$ is moderate, while the value of diversity index (E') is balanced. The value of the Dominancy index (D) is medium, where no species are dominated. The abundance of the highest zooplankton is in the afternoon intake of 176 ind./L and the lowest on the morning intake of 52 Ind./L.
\end{abstract}

Kata Kunci: Koeono, Waters, Community Structure, Zooplankton.

\section{Pendahuluan}

Zooplankton memiliki peranan yang sangat penting di lautan, dimana zooplankton merupakan kunci tingkatan trofik terendah (fitoplankton) ke tingkatan trofik tertinggi (sumber daya ikan) dalam rantai makanan di lautan. Atmosfer dan lautan saling berinteraksi, artinya perubahan yang terjadi pada atmosfer (iklim) akan berpengaruh pada proses-proses yang terjadi di lautan dan sebaliknya. Perubahan karakteristik massa air laut yang disebabkan oleh pengaruh iklim seperti perubahan lapisan homogen (mixed layer) akan berpengaruh pada dinamika biota laut khususnya zooplankton. Sebaliknya, zooplankton memiliki peranan penting dalam menyeimbangkan iklim, zooplankton merupakan kunci pembawa karbon dioksida ke laut dalam. Seperti yang kita ketahui bahwasanya karbon dioksida merupakan senyawa yang menyebabkan pemanasan global (Kaswadji, 2001).

Zooplankton di perairan terdapat di permukaan laut hingga kedalaman $200 \mathrm{~m}$. Pada siang hari zooplankton lebih banyak ditemukan ke arah dasar laut dan kepermukaan pada malam hari (migrasi vertikal harian). Zooplankton akan bergerak menjauhi permukaan bila intensitas cahaya matahari dipermukaan meningkat dan 
zooplankton bergerak kepermukaan bila intensitas cahaya matahari menurun.

Kabupaten Konawe Selatan merupakan salah satu kabupaten yang ada di Provinsi Sulawesi Tenggara yang berada di wilayah pesisir laut sangat besar. Kabupaten Konawe Selatan juga memiliki sumber daya berupa hasil perikanan dan cadangan mineral berupa nikel. Selain memberikan konstribusi bagi pemerintah dan masyarakat setempat, pertambangan juga akan menimbulkan dampak negatif terhadap lingkungan sekitar apalagi pertambangan yang letaknya dipinggir laut. Kegiatan pertambangan yang berlangsung secara menerus memberikan dampak buruk terhadap ekosistem yaitu ekosistem mangrove, lamun dan terumbu karang. Rusaknya salah satu ekosistem tersebut maka akan berdampak pada biota yang ada di perairan tersebut.

Tujuan dari penelitian ini adalah untuk mengetahui struktur komunitas dan kelimpahan zooplankton di Perairan Koeonokarena kelimpahan zooplankton dapat menggambarkan keadaan suatu perairan maupun ketersediaan makanan untuk menunjang kehidupan biota, sehingga produktivitas perairan dapat dilihat dari struktur komunitas zooplankton.

\section{Bahan dan Metode}

Pengambilan data dilaksanakan pada Februari-Desember 2019, bertempat di Perairan Koeono, Desa Koeono, Kecamatan Palangga Selatan, Kabupaten Konawe Selatan. Sampel zooplankton dan parameter kualitas air (DO) dianalisis di Laboratorium Unit Produktivitas dan Lingkungan Perairan, Fakultas Perikanan dan Ilmu Kelautan, Universitas Halu Oleo, Kendari.

Prosedur penelitian meliputi survey pendahuluan, penentuan stasiun penelitian dan pengambilan data serta pengukuran parameter lingkungan. Survey pendahuluan dilakukan untuk mengetahui kondisi lokasi penelitian, penentuan titik stasiun dalam pengambilan sampel dan persiapan yang akan digunakan di lapangan.

Titik koordinat setiap stasiun pengamatan pada lokasi penelitian di Perairan Koeono terdiri dari 3 stasiun. Stasiun I, berada di titik koordinat $4^{\circ} 27^{\prime} 51,58^{\prime \prime}$ LS $122^{\circ} 22^{\prime} 43,82^{\prime \prime}$ BT, di stasiun ini masih dipengaruhi aliran sungai. Stasiun II, berada didekat jety tempat bersandarnya kapal-kapal pengangkut hasil tambang dengan titik koordinat $4^{\circ} 28^{\prime} 9,40^{\prime \prime}$ LS - $122^{\circ} 22^{\prime} 46,56^{\prime \prime}$ BT. Stasiun III, berada di perairan yang luas dan sudah tidak dipengaruhi aktifitas tambang dengan titik koordinat $4^{\circ} 28^{\prime} 27,07^{\prime \prime}$ LS $122^{\circ} 22^{\prime} 7,46^{\prime \prime}$ BT.

Pengambilan sampel dilakukan selama 1 bulan. Pengambilan sampel dilakukan sebanyak 2 kali dengan interval waktu pengambilan sampel tiap 1 kali dalam 2 minggu. Pengambilan sampel zooplankton dilakukan pada tiga stasiun dengan kedalaman yang berbeda yaitu pada kedalaman $0,5 \mathrm{~m}, 5$ $\mathrm{m}$ dan $10 \mathrm{~m}$. Pengambilan sampel dilakukan pada pagi hari pukul 08.00-10.00 dan pada sore hari pukul 16.00-18.00 WITA.



Gambar 1. Pengambilan Sampel disetiap stasiun di Perairan Koeono 
Tabel 1. Alat dan Bahan yang digunakan dalam Penelitian

\begin{tabular}{|c|c|c|c|c|}
\hline No. & Alat / Bahan & Satuan & Kegunaan & $\begin{array}{c}\text { Jumlah } \\
\text { Unit }\end{array}$ \\
\hline A. & Alat & & & \\
\hline 1. & Kamera & unit & Dokumentasi & 1 \\
\hline 2. & Stopwatch & $\mathrm{S}$ & Mengukur waktu & 1 \\
\hline 3. & Thermometer & ${ }^{0} \mathrm{C}$ & Pengukuran suhu air & 1 \\
\hline 4. & Secchidisk & $\%$ & Pengukuran kecerahan & 1 \\
\hline 5. & Layang arus & $\mathrm{m} / \mathrm{s}$ & Pengukuran kecepatan arus & 1 \\
\hline 6. & Hendrofractometer & ppt & Pengukuran Salinitas & 1 \\
\hline 7. & Spektrofotometer & $\mathrm{mg} / \mathrm{L}$ & Pengukuran oksigen terlarut & 1 \\
\hline 9. & Kertas pH & unit & Pengukuran $\mathrm{pH}$ & 1 \\
\hline 10. & Plankton net & unit & Menyaring sampel & 1 \\
\hline 11. & Mikroskop & mikron & $\begin{array}{l}\text { Mengidentifikasi jenis-jenis } \\
\text { zooplankton }\end{array}$ & 1 \\
\hline 12. & $\begin{array}{l}\text { SRC (Sedgewick } \\
\text { Rafter Cell) }\end{array}$ & unit & $\begin{array}{l}\text { Mengidentifikasi jenis-jenis } \\
\text { zooplankton }\end{array}$ & 1 \\
\hline 13. & GPS digital & unit & $\begin{array}{l}\text { Menentukan titik koordinat } \\
\text { stasiun }\end{array}$ & 1 \\
\hline 14. & Alat Tulis & benda & Mencatat data & 1 \\
\hline 15. & Ember (10 liter) & unit & Menampung air & 1 \\
\hline 16. & Perahu & benda & Alat transportasi & 1 \\
\hline 17. & Botol & unit & Menyimpan sampel & 1 \\
\hline 18. & Kertas label & unit & Menandai sampel & 1 \\
\hline 19. & $\begin{array}{l}\text { Buku kunci } \\
\text { identifikasi } \\
\text { zooplankton, } \\
\text { (Botes, 2003) dan } \\
\text { Yamaji (1966). }\end{array}$ & buku & $\begin{array}{l}\text { Buku panduan mengidentifikasi } \\
\text { jenis zooplankton yang diamati }\end{array}$ & 1 \\
\hline B. & Bahan & & & \\
\hline 1. & Lugol & $\mathrm{ml}$ & Mengawetkan sampel & - \\
\hline 2. & Larutan $\mathrm{MnSO}_{4}$ & $\mathrm{ml}$ & Pengikat DO & - \\
\hline
\end{tabular}

Sampel zooplankton diambil dengan cara menyaring air disetiap kedalaman dengan menggunakan pompa air yang disambungkan dengan pipa, selanjutnya pipa diturunkan di kedalaman yang telah ditentukan. Sampel air yang diambil sebanyak 100 liter yang disaring menggunakan plankton net dengan ukuran 25 $\mathrm{mm}$. Hasil penyaringan dimasukkan ke dalam botol sampel dengan volume $100 \mathrm{ml}$ dan diberi 5 tetes lugol, kemudian botol sampel disimpan sebelum diidentifikasi. Setelah itu dibawa ke Laboratorium diidentifikasi jenisnya.

Prosedur kerja pada analisis sampel zooplankton di Laboratorium di lakukan dengan langkah-langkah sebagai berikut :

1) Menyiapkan alat dan bahan (mikroskop, SRC, pipet ukur, aquades, tissu dan sampel yang diamati).

2) Selanjutnya menghomogengkan sampel (sampel dikocok selama 30 detik dengan kecepatan standar).
3) Mengambil sampel air yang telah dihomogengkan dengan pipet ukur sebanyak $1 \mathrm{ml}$ dalam 1 botol sampel dan diletakkan pada SRC.

4) Selanjutnya sampel zooplankton diamati diabawah mikroskop binokuler (pembesaran 4x10) dengan pola " zig zag" dari kiri ke kanan.

5) Mengidentifikasi jenis zooplankton yang ditemukan menggunakan buku kunci identifikasi plankton Botes (2003) dan Yamaji (1996).

6) Menghitung jumlah jenis zooplankton yang ditemukan pada setiap $1 \mathrm{ml}$ sampel air.

7) Selanjutnya mengulangi perlakuan sampai semua sampel air yang sebanyak 36 botol telah habis.

8) Mendokumentasikan setiap jenis sampel zooplankton yang ditemukan. 
Parameter lingkungan perairan yang diukur adalah suhu, kecepatan arus, kecerahan, salinitas, $\mathrm{pH}$, dan Disolved Oxygen (DO). Suhu diukur dengan menggunakan Thermometer pada setiap stasiun dengan tiap-tiap kedalaman. Pengamatan dengan cara mencelupkan ke dalam perairan dan mencatat suhu perairan hasil penunjukkan termometer. Pengukuran arus dilakukan disetiap stasiun pengamatan.

Pengukuran kecepatan arus dilakukan dengan melepas layang-layang arus dengan stopwatch, dan melihat arah arus dengan kompas bidik dengan mengamati pergerakan layang-layang arus dan mencatat hasil yang didapatkan. Kecepatan arus diketahui dengan cara menghitung selang waktu (t) yang dibutuhkan layang arus untuk menempuh jarak (s) dengan rumus:

$\mathrm{V}=\frac{s}{t}$

Dimana :

$\mathrm{V}=$ Kecepatan arus (m/detik)

$\mathrm{s}=$ Jarak tempuh layang-layang arus (m)

$\mathrm{t}=$ Waktu yang digunakan (detik)

Menurunkan Secchidisk sampai hilang dari pandangan. Menurunkan sepertiga meter dan kemudian perlahan-lahan mengangkat disk sampai terlihat kembali. Gerakkan disk ke atas dan ke bawah sampai titik hilang yang tepat ditemukan. Pasang jepitan di tali pada titik tali masuk ke air.Mencatat hasil pengukuran. Untuk mengukur kecerahan perairan menggunakan

rumus

berikut:

$\mathrm{N}=\frac{d 1+d 2}{2}$

Dimana :

$\mathrm{N}=$ Kecerahan

$\mathrm{d} 1=$ Kedalaman secchidisk saat tidak terlihat

$\mathrm{d} 2$ = Kedalaman secchidisk saat mulai tampak kembali

Pengukuran salinitas dengan menggunakan Handrefractometer. Nilai salinitas suatu perairan diukur perkedalaman disetiap stasiun. Pengukuran $\mathrm{pH}$ (derajat keasaman) air laut menggunakan $\mathrm{pH}$ indikator dengan perkedalaman disetiap stasiun. Caranya yaitu dengan mencelupkan $\mathrm{pH}$ indikator ke air laut, lalu mengangkat $\mathrm{pH}$ indikator kemudian mencatat hasil yang didapatkan.

Pengambilan sampel DO menggunakan botol volume $\pm 300 \mathrm{ml}$ yang bersih dan tidak tembus cahaya matahari langsung. Saat pengisian, botol dicelupkan ke dalam air dan menghindari terjadinya turbulensi dengan gelembung udara yang masuk ke dalam botol. Pengambilan sampel DO dilakukan disetiap kedalaman.

\section{Analisis Data}

Kelimpahan zooplankton dihitung dengan metode sensus menggunakan Sedgewick rafter cell (SRC) yang dihitung berdasarkan formula dari APHA (2005). Yaitu pada persamaan berikut :

$\mathrm{K}=\frac{N}{A c} x \frac{A t}{V s} x \frac{V t}{A s}$

Dimana :

$\mathrm{K}$ = Kelimpahan zooplankton (ind/L)

$\mathrm{N}=$ Kelimpahan spesies

At $=$ Luas penampang permukaan SRC (SRC $=1000$ )

$\mathrm{Ac}=$ Luas amatan $(\mathrm{SRC}=1000)$

$\mathrm{Vs}=$ Volume air konsentrasi dalam SRC (ml)

$\mathrm{Vt}=$ Volume konsentrasi botol contoh $(\mathrm{ml})$

As $=$ Volume air yang disaring $(\mathrm{L})$

Keanekaragaman dihitung dengan menggunakan rumus indeks keanekaragaman "shannon indeks of diversity" (Odum, 1993) : $\mathrm{H}^{\prime}=-\sum \frac{n i}{N} \operatorname{Ln} \frac{n i}{N}$

Dimana :

$\mathrm{H}^{\prime}=$ Indeks keanekaragaman

$\mathrm{ni}=$ Jumlah individu spesies ke-I (ind)

$\mathrm{N}=$ Jumlah total individu

Menurut Fatiqoh $d k k$. (2015), kisaran indeks keanekaragaman adalah sebagai berikut: Jika $\mathrm{H}^{\prime}<3=$ Keanekaragaman rendah; $1<\mathrm{H}^{\prime}<$ = Keanekaragaman sedang; dan $\mathrm{H}^{\prime}>=$ Keanekaragaman tinggi.

Keseragaman dihitung dengan menggunakan rumus indeks keseragaman (Odum, 1993), sebagaimana persamaan berikut :

$H^{\prime}=\frac{H^{\prime}}{H^{\prime} m a k s}$

Dimana :

E' = Indeks keseragaman

$\mathrm{H}^{\prime}=$ Indeks keanekaragaman

$\mathrm{H}^{\prime}{ }_{\text {maks }}=\mathrm{Ln} \mathrm{S}$

$\mathrm{S}=$ Jumlah Spesies yang ditemukan

Menurut Fatiqoh $d k k$. (2015), kisaran nilai indeks keseragaman berkisar 0-1 adalah sebagai berikut, jika E' (1) = Keseragaman seimbang; $E^{\prime}>1$ = Keseragaman rendah; dan $\mathrm{E}^{\prime}<1=$ Keseragaman tinggi.

Dominansi dihitung dengan menggunakan indeks "indeks of dominance" dari Simpson (Odum, 1993) adalah sebagai berikut : 
$\mathrm{C}=\frac{\sum n i(n i-1)}{N(N-1)}$

Dimana :

$\mathrm{C}=$ Indeks dominansi

$\mathrm{ni}=$ Jumlah individu spesies ke-i

$\mathrm{N}=$ jumlah total individu

\section{Hasil dan Pembahasan}

Berdasarkan hasil perhitungan, didapatkan nilai keeanekaragaman pada pagi dan sore hari, nilai yang didapatkan tidak jauh berbeda dan dengan nilai kisaran yaitu pagi hari $(1,761-2,044)$ dan sore hari dengan nilai $(2,008-2,667)$. Berdasarkan nilai keaneka-ragaman yang didapatkan menunjukkan bahwa nilai keanekaragaman berada pada kondisi stabil.Hal ini sesuai dengan pendapat Siro $d k k$. (2019), apabila $\mathrm{H}^{\prime}<1$, maka komunitas biota dinyatakan tidak stabil, apabila $H^{\prime}$ berkisar 1-3 maka stabilitas komunitas berada dalam kondisi stabil. Nilai indeks keanekaragaman yang didapatkan dalam penelitian ini diduga tidak terlepas dari kelimpahan zooplankton yang ditemukan pada penelitian ini, karena semakin rendah atau tingginya nilai kelimpahan zooplankton maka akan semakin rendah atau melimpah pada keanekaragaman zooplankton dalam suatu perairan. Hal ini sesuai dengan pernyataan Siagian (2012), bahwa nilai kelimpahan yang rendah pada suatu komunitas maka tingkat indeks keanekaragamannya juga akan menurun karena keanekaragaman ditentukan oleh jumlah jenis dan individu suatu komunitas.

Keanekaragaman untuk setiap stasiun di Perairan Koeono menunjukkan suatu bentuk keanekaragaman jenis yang sedang. Hal ini didasarkan atas pernyataan Puspita $d k k$. (2018), bahwa kisaran nilai indeks keanekaragaman 0-1 menunjukkan bahwa daerah tersebut terdapat tekanan ekologis yang tinggi dan indeks keanekaragaman jenis yang rendah. Kisaran 1-3 menunjukkan indeks keanekaragaman yang sedang, untuk nilai keanekaragaman yang lebih besar dari 3 menunjukkan keadaan suatu daerah yang mengalami tekanan ekologi rendah dan indeks keanekaragaman spesiesnya tinggi. Keanekaragaman juga ditunjang oleh komunitas plankton itu sendiri dimana plankton akan berkumpul disuatu tempat yang disukai.

Tabel 2. Jenis Zooplankton yang Ditemukan Selama Periode Penelitian

\begin{tabular}{lllll}
\hline No & Kelas & Ordo & Family & Genus \\
\hline \multirow{2}{*}{ Crustacea } & Calanoida & Arthropoda & Copepoda \\
& & Calanoida & Tortanidae & Tortanus \\
& & Calanoida & Pseudodiptomidae & Schemackeria \\
& & Calanoida & Pseudodiptomidae & Microsetella \\
& & Asterales & Compositae & Nauplius \\
\hline 2 & Maxillopoda & Calanoida & Acartidae & Acartia \\
& & Sessillia & Balanidae & Brachionus \\
& & Sessillia & Ameridae & Nitocra \\
\hline 3 & Cilliatea & Choreotrchida & Phyhocylididae & Favella \\
& & Choreotrchida & Phyhocylididae & Paravella \\
\hline 4 & Hexanauplia & Cyclopoida & Cyclopoidae & Apocyclopas \\
& & Cyclopoida & Oithonidae & Oithona \\
& & Harpaticoida & Canthocamptidae & Echinocamptus \\
& & Harpaticoida & Canthocamptidae & Cletocamptus \\
\hline 5 & Olighotrichea & Choreotrchida & Codonellopsidae & Codonellopsis \\
& & Choreotrchida & Tintinopsidae & Tintinopsis \\
\hline
\end{tabular}


Tabel 3. Nilai Indeks Keanekaragaman (H'), Keseragaman (E) dan Dominansi (C) Zooplankton pada Pagi Hari (08.00-10.00) di Perairan Koeono.

\begin{tabular}{ccccccccccc}
\hline & \multicolumn{10}{c}{ Indeks Biologi } \\
\cline { 2 - 10 } Kedalaman & \multicolumn{1}{c}{ Keanekaragaman (H') } & \multicolumn{3}{c}{ Keseragaman (E) } & \multicolumn{3}{c}{ Dominansi ( C ) } \\
\cline { 2 - 11 } & I & II & III & I & II & III & I & II & III \\
\hline \multirow{2}{*}{$0,5 \mathrm{M}$} & 1,761 & 1,978 & 1,873 & 0,450 & 0,893 & 0,897 & 0,471 & 0,123 & 0,096 \\
$5 \mathrm{M}$ & 1,768 & $2,044^{*}$ & 1,869 & 0,882 & 0,959 & 0,891 & 0,130 & 0,130 & 0,127 \\
$10 \mathrm{M}$ & 1,802 & 2,005 & 2,000 & 0,958 & $0,960^{*}$ & 0,929 & 0,144 & 0,102 & $0,633^{*}$ \\
\hline Kisaran & \multicolumn{3}{c}{$1,761-2,044$} & \multicolumn{1}{c}{$0,450-0,960$} & & $0,096-0,633$ & \\
\hline
\end{tabular}

Ket: I, II, III = Stasiun

$=$ Nilai Tertinggi

Tabel 4. Nilai Indeks Keanekaragaman (H'), Keseragaman (E) dan Dominansi (C) Zooplankton pada Sore Hari (16.00-18.00) di Perairan Koeono.

\begin{tabular}{ccccccccccc}
\hline \multirow{2}{*}{ Kedalaman } & \multicolumn{10}{c}{ Indeks Bologi } \\
\cline { 2 - 10 } & \multicolumn{1}{c}{ Keanekaragaman (H') } & \multicolumn{1}{c}{ Keseragaman (E) } & \multicolumn{3}{c}{ Dominansi ( C ) } \\
\cline { 2 - 10 } & I & II & III & I & II & III & I & II & III \\
\hline \multirow{2}{*}{$0,5 \mathrm{M}$} & 2,008 & 2,250 & 2,374 & 0,877 & 0,521 & 0,900 & 0,226 & 0,112 & 0,119 \\
$5 \mathrm{M}$ & 2,053 & 2,612 & 2,520 & 0,891 & 0,954 & 0,925 & 0,146 & 0,080 & 0,090 \\
$10 \mathrm{M}$ & 2,111 & 2,520 & $2,667 *$ & 0,919 & 0,955 & $0,962 *$ & 0,142 & $0,503 *$ & 0,105 \\
\hline Kisaran & $2,008-2,667$ & \multicolumn{3}{c}{$0,521-0,962$} & $0,080-0.503$ & & \\
\hline Keterangan: & I, II, III = Stasiun; & $*$ & $=$ Nilai Tertinggi & & & &
\end{tabular}

Berdasarkan hasil analisis (Tabel 3) diperoleh nilai indeks keseragaman pada pagi hari (08.00-10.00) nilai tertinggi sebesar 0,960 terdapat pada stasiun II dengan kedalaman 10 meter dan terendah pada stasiun I kedalaman $0,5 \mathrm{~m}$ dengan nilai 0,450 dan sore hari (16.00-19.00) nilai indeks keseragaman tertinggi (Tabel 4) dengan nilai 0,962 terdapat pada stasiun I dengan kedalaman $10 \mathrm{~m}$ dan terendah dengan nilai 0,521 terdapat pada stasiun II dengan kedalaman $0,5 \mathrm{~m}$. Nilai indeks keseragaman yang diperoleh selama penelitian di Perairan Koeono cenderung mendekati 1 yang berarti keseragaman antara spesies relatif seimbang atau jumlah individu masing-masing spesies tidak jauh berbeda. Menurut Junaldi $d k k$. (2018), terjadinya perbedaan nilai indeks keseragaman pada setiap stasiun dapat terjadi karena jumlah jenis dan kelimpahan jenis masing-masing zooplankton berbeda sehingga akan memengaruhi nilai indeks keseragaman. Hal ini diperkuat oleh Dewanti $d k k$. (2018), mengemukakan bahwa nilai indeks keseragaman berkisar 0-1. Jika nilai indeks keseragaman mendekati $1(>0,5)$, berarti keseragaman organisme dalam suatu perairan berada dalam keadaan seimbang, berarti tidak terjadi persaingan baik terhadap tempat maupun makanan.

Tingginya nilai indeks keseragaman pada stasiun II (pagi hari) dengan kedalaman $10 \mathrm{~m}$ dan stasiun I (sore hari) dengan kedalaman $10 \mathrm{~m}$, pada saat pengambilan sampel di kedalaman $10 \mathrm{~m}$ menunjukkan bahwa pada saat itu tidak ada genus yang mendominasi atau penyebaran tiap genus cenderung merata. Hal ini diduga karena kondisi parameter lingkungan Perairan Koeono pada saat itu memiliki daya dukung yang baik seperti suhu $\left(29-32^{\circ} \mathrm{C}\right)$, salinitas (31-34 ppt), pH (6,5-7 ppm). Keseragaman zooplankton setiap kedalaman tidak berbeda nyata, dari hasil analisis menunjukkan bahwa nilai keseragaman mendekati 1 yang artinya tidak ada jenis zooplankton yang mendominasi pada Perairan Koeono apalagi pada kedalaman yang berbeda. 


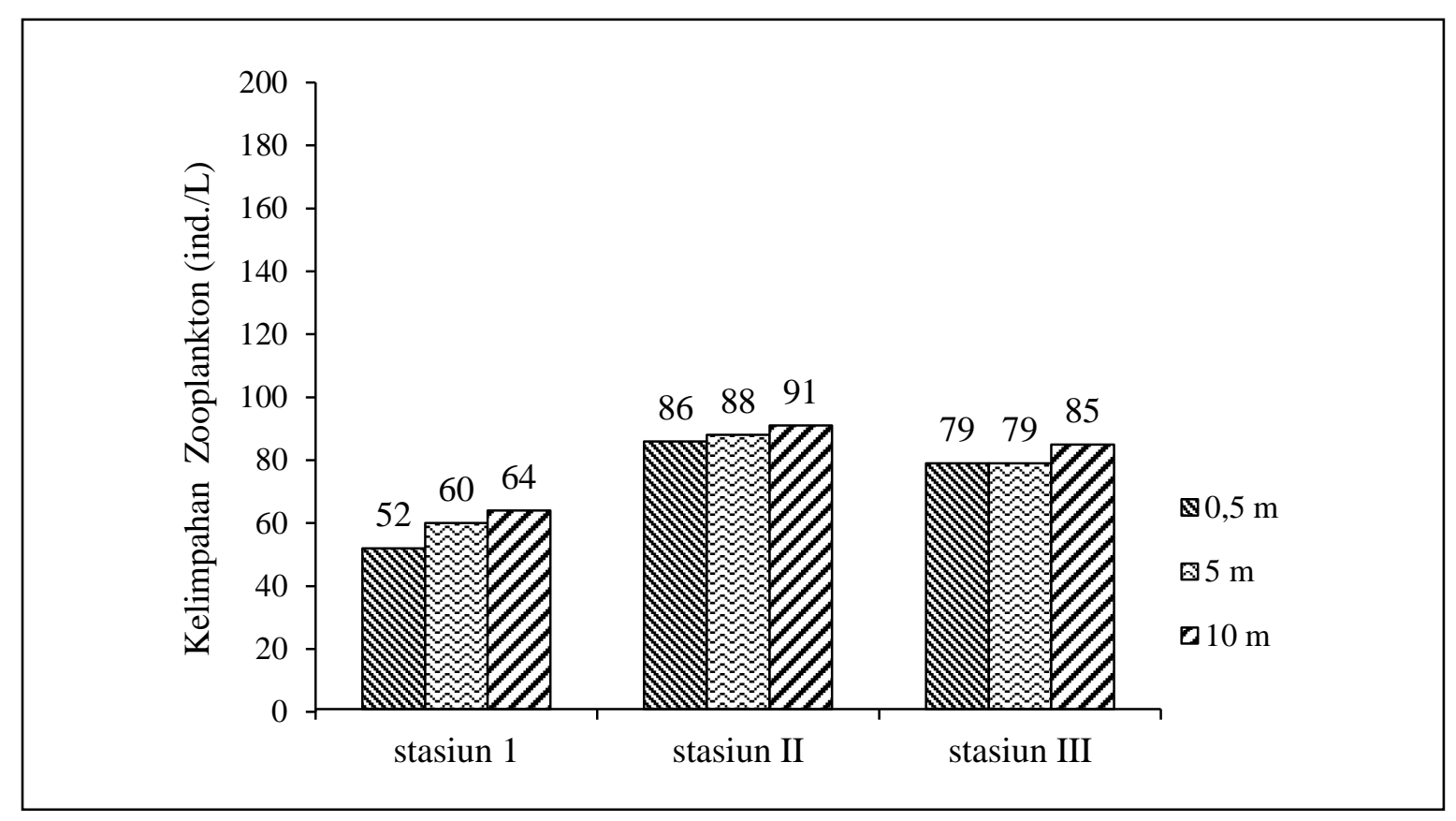

Gambar 2. Kelimpahan Zooplankton di Perairan Koeono Pagi Hari (08.00-10.00)

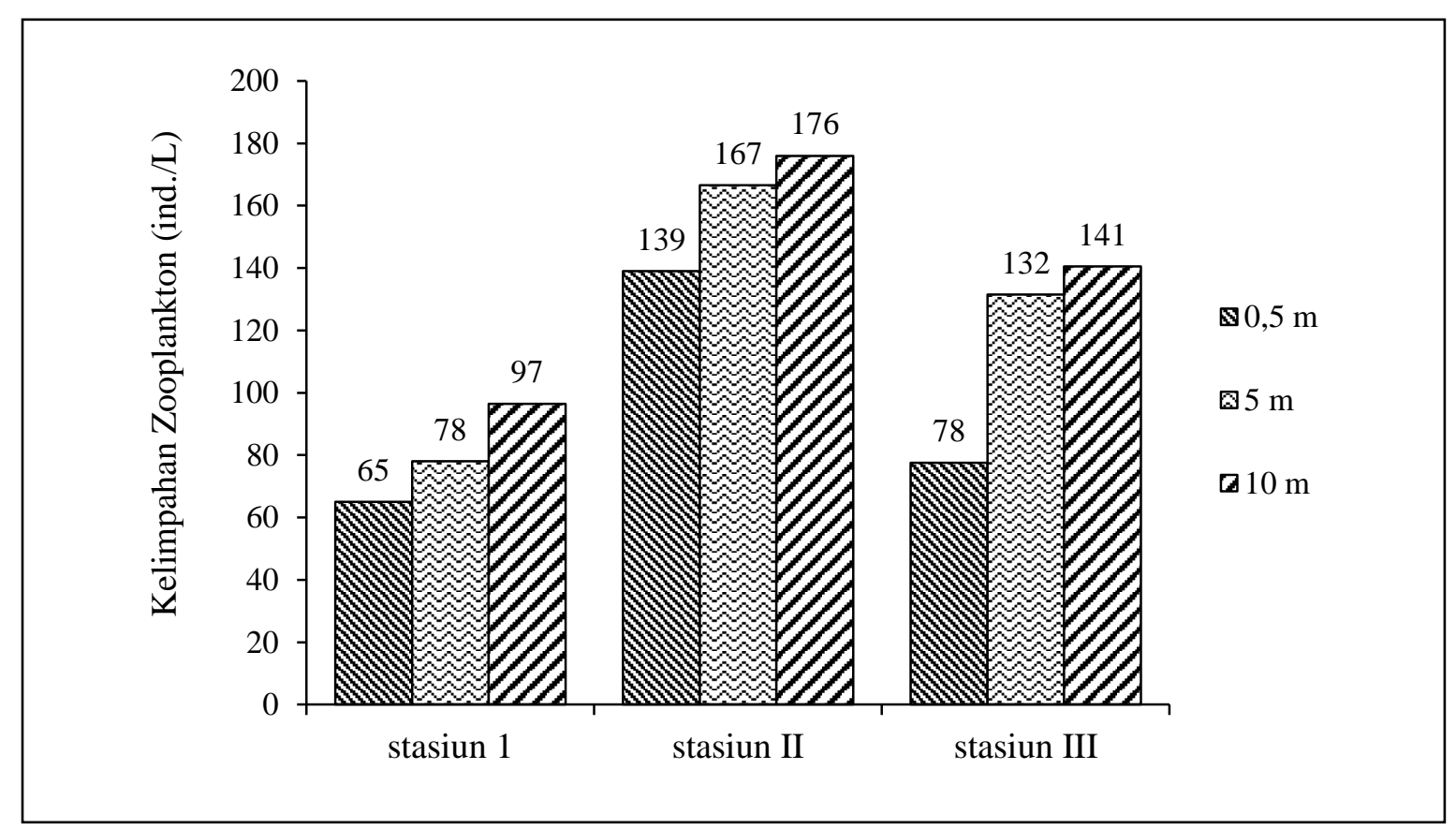

Gambar 4. Gambar 3. Kelimpahan Zooplankton di Perairan Koeono Sore Hari (16.00-18.00)

Berdasarkan hasil penelitian pada pagi hari (08.00-10.00) nilai rata-rata kelimpahan yang didapatkan yaitu berkisar 52-91 ind./L (Gambar 3). Nilai kelimpahan ini berbeda dengan nilai rata-rata kelimpahan pada sore hari yaitu berkisar $65-176$ ind./L. Hal ini karena jumlah genera zooplankton yang didapatkan pada pagi hari lebih sedikit yaitu 8 genera dibandingkan pada sore hari $(08.00-$ 18.00) sebanyak 16 genera. Zooplankton dikenal dengan migrasi vertikal harian namun hanya pada organisme tertentu ke arah dasar laut permukaan pada malam hari. Tambaru $d k k$. (2014), zooplankton bergerak lebih kedalam menjauhi permukaan laut dan biasanya mempertahankan posisinya pada kedalaman dengan instensitas cahaya tertentu, di tengah hari atau ketika intensitas cahaya matahari maksimal, zooplankton berada pada kedalaman paling jauh. 
Tabel 5. Parameter Fisika dan Kimia Perairan Koeono pada Pagi Hari (08.00-10.00).

\begin{tabular}{llcccc}
\hline \multirow{2}{*}{ No } & \multirow{2}{*}{ Parameter } & $\begin{array}{c}\text { Kedalaman } \\
(\mathbf{m})\end{array}$ & $\mathbf{I}$ & II & III \\
\cline { 4 - 6 } 1 & \multirow{2}{*}{ Suhu $\left(\mathrm{C}^{\circ}\right)$} & 0,5 & 30 & 32 & 29,5 \\
& & 5 & 30 & 30 & 29,5 \\
& & 10 & 29 & 29,5 & 29 \\
\hline 2 & \multirow{2}{*}{ Kecerahan $(\mathrm{m})$} & 0,5 & 5,25 & 6 & 6,25 \\
& & 5 & 5,25 & 6 & 6,25 \\
& & 10 & 5,25 & 6 & 6,25 \\
\hline 3 & \multirow{2}{*}{ Kecepatan arus $(\mathrm{m} / \mathrm{s})$} & 0,5 & 0,2 & 0,05 & 0,08 \\
& & 5 & 0,2 & 0,06 & 0,08 \\
& & 10 & 0,3 & 0,06 & 0,07 \\
\hline 4 & \multirow{2}{*}{$\mathrm{pH}$} & 0,5 & 6 & 7 & 7 \\
& & 5 & 6 & 7 & 7 \\
& & 10 & 6 & 7 & 7 \\
\hline 5 & \multirow{2}{*}{ DO (mg/L) } & 0,5 & 6,6 & 6,6 & 6,6 \\
& & 5 & 6,5 & 6,5 & 6,5 \\
& & 10 & 6,4 & 6,5 & 6,3 \\
\hline 6 & Salinitas (ppt) & 0,5 & 31 & 32 & 34 \\
& & 5 & 31 & 32 & 34 \\
& & 10 & 31 & 32 & 34 \\
\hline
\end{tabular}

Tabel 6. Parameter Fisika dan Kimia Perairan Koeono pada Sore Hari (16.00-18.00).

\begin{tabular}{|c|c|c|c|c|c|}
\hline \multirow{2}{*}{ No } & \multirow{2}{*}{ Parameter } & \multirow{2}{*}{$\begin{array}{c}\text { Kedalaman } \\
(\mathbf{m})\end{array}$} & \multicolumn{3}{|c|}{ Stasiun } \\
\hline & & & $\mathrm{I}$ & II & III \\
\hline \multirow[t]{3}{*}{1} & Suhu $\left(C^{\circ}\right)$ & 0,5 & 31 & 32 & 30,5 \\
\hline & & 5 & 30 & 29 & 29 \\
\hline & & 10 & 29 & 28 & 28 \\
\hline \multirow[t]{3}{*}{2} & Kecerahan (m) & 0.5 & 6,25 & 8,5 & 7,75 \\
\hline & & 5 & 6,25 & 8,5 & 7,75 \\
\hline & & 10 & 6,25 & 8,5 & 7,75 \\
\hline \multirow[t]{3}{*}{3} & Kecepatan Arus (m/s) & 0,5 & 0,3 & 0,04 & 0,08 \\
\hline & & 5 & 0,2 & 0,08 & 0,07 \\
\hline & & 10 & 0,3 & 0,07 & 0,07 \\
\hline \multirow[t]{3}{*}{4} & $\mathrm{pH}$ & 0,5 & 6 & 7 & 7 \\
\hline & & 5 & 6 & 7 & 7 \\
\hline & & 10 & 6 & 7 & 7 \\
\hline \multirow[t]{3}{*}{5} & $\mathrm{DO}(\mathrm{mg} / \mathrm{L})$ & 0,5 & 6,55 & 6,75 & 6,2 \\
\hline & & 5 & 6,5 & 6,35 & 6,1 \\
\hline & & 10 & 6,2 & 6,75 & 6,4 \\
\hline \multirow[t]{3}{*}{6} & Salinitas (ppt) & 0,5 & 32,5 & 33 & 32,5 \\
\hline & & 5 & 31,5 & 32 & 31,5 \\
\hline & & 10 & 31 & 31 & 31 \\
\hline
\end{tabular}


Kelimpahan zooplankton pada pagi hari (08.00-10.00) dan sore hari (16.00-18.00) dengan nilai tertinggi yaitu 91-176 ind./L. Nilai kelimpahan tertinggi pada pagi hari terdapat pada stasiun II yakni 91 ind./L dan nilai kelimpahan pada sore hari yaitu pada stasiun yang sama yaitu stasiun II dengan nilai 176 ind./L. Tingginya kelimpahan pada stasiun II salah satunya dikarenakan kelimpahan fitoplankton di stasiun II cukup tinggi yaitu pagi hari 189 ind./L dan sore hari berkisar $281 \mathrm{sel} / \mathrm{L}$ (Azis, 2019) dimana nilai kelimpahan ini masuk kategori tertinggi dibandingkan dengan stasiun lain. Sehingga kelimpahan zooplankton berbanding lurus dengan tingginya kelimpahan fitoplankton di Perairan Koeono. Hal ini diperkuat dengan pernyataan Puspita dkk. (2018), bahwa melimpahnya fitooplankton yang berperan sebagai sumber makanan bagi zooplankton dan menandakan perairan tersebut memiliki tingkat kesuburan dengan kategori eutropik. Menurut Dewanti $d k k$. (2018), bahwa zooplankton yang bersifat herbivora memakan fitoplankton secara langsung, sedangkan secara tidak langsung zooplankton yang bersifat karnivora lain yang umumnya mempunyai ukuran tubuh yang lebih kecil. Hal ini sejalan dengan pernyataan Nybakken (1992), yang menyatakan bahwa intensitas cahaya matahari dapat menyebabkan respon negatif bagi organisme yang melakukan migrasi. Zooplankton akan bergerak menjauhi permukaan perairan apabila intensitas cahaya matahari meningkat dan mendekati permukaan apabila intensitas cahaya matahari menurun. Selain intensitas cahaya matahari dikarenakan keadaan suhu perairan normal yang berkisar 29-32, juga mempengaruhi kelimpahan zooplankton. Menurut Siro $d k k$. (2013), suhu perairan mempengaruhi keberadaan zooplankton secara fisiologis dan ekologis. Secara fisiologis, perbedaan suhu perairan sangat berpengaruh terhadap umur dan ukuran zooplankton dewasa. Secara ekologis, perubahan suhu menyebabkan perbedaan komposisi dan kelimpahan zooplankton.

Kelimpahan zooplankton terendah pada pagi hari dan sore hari terletak pada stasiun yang sama yaitu stasiun I. Kelimpahan pada pagi hari berkisar 52-64 ind./L dari kedalaman 0,5 sampai $10 \mathrm{~m}$, kelimpahan pada sore hari berkisar antara 65-97 ind./L. Kelimpahan stasiun I lebih rendah dibandingkan dengan kedua stasiun lainnya hal ini dikarenakan stasiun ini terletak pada daerah muara sungai sehingga organisme di stasiun ini lebih sedikit. Hal ini sesuai dengan pernyataan Tawuning $d k k$. (2018), bahwa kondisi fisika dan kimia pada muara sungai umumnya mempunyai variasi yang sangat besar. Hal ini mengakibatkan organisme zooplankton yang berada di perairan tersebut menjadi tertekan. Sehingga jumlah spesies yang dapat hidup menjadi lebih sedikit dibandingkan dengan perairan lainnya, seperti perairan laut dan tawar.

Kelimpahan zooplankton terbanyak ditemukan dari kelas Crustacea dari genus Copepoda, Tortanus, Schemackeria, Microsetella dan Nauplius. Kelas crustacea dapat bertahan hidup dengan baik dalam berbagai habitat. Kemampuan adaptasi dari kelas Cructasea khususnya jenis copepoda sangat tinggi dalam berbagai kondisi. Hal ini sejalan dengan penelitian Salwiyah $d k k$. (2018), bahwa melimpahnya keberadaan copepoda di perairan ialah disebabkan copepoda dapat bertahan hidup dengan baik dalam berbagai habitat, copepoda mampu bertahan pada perubahan kondisi lingkungan yang ekstrim seperti pada suhu $17-30{ }^{\circ} \mathrm{C}$ dan pH 8. Nybakken (1992), menyatakan bahwa diantara semua zooplankton, copepoda memiliki exoceleton terberat dan terpanjang serta pelengkap terkuat yang membantu mereka untuk bergerak lebih cepat dibandingkan zooplankton jenis lainnya. Sachlan (1982), menyatakan bahwa copepoda dari ordo Calanoida dan Harpactinoida adalah zooplankton berukuran kecil yang mendominasi diseluruh perairan bahari. Copepoda dalam ekosistem perairan merupakan zooplankton yang dominan dengan populasi yang mencapai $70-80 \%$.

Berdasarkan Tabel 6 dan Tabel 7 nilai DO di Perairan Koeono pada pagi hari dan sore hari berkisar antara $6,1 \mathrm{mg} / \mathrm{L}-6,75 \mathrm{mg} / \mathrm{L}$. Nilai DO tertinggi terdapat pada stasiun II dengan nilai $6,75 \mathrm{mg} / \mathrm{L}$ hal ini berbanding lurus dengan kelimpahan zooplankton yang didapatkan dimana kelimpahan tertinggi terdapat pada stasiun II. Hal ini dikarenakan melimpahnya fitoplankton di stasiun II tersebut, karena adanya fitoplankton yang melimpah pada stasiun ini, sehingga terjadi proses fotosintesis yang menghasilkan oksigen terlarut sebagai faktor pembatas dalam lingkungan perairan. Hal ini sesuai 
dengan pendapat Augusta dan Evi (2014), bahwa oksigen terlarut dalam air berasal dari hasil fotosintesis fitoplankton dan difusi dari udara.

Penurunan kadar oksigen terlarut sampai batas tertentu dapat menimbulkan kematian bagi organisme di perairan. Berdasarkan baku mutu Keputusan Menteri Lingkungan Hidup No. 51 Tahun 2004 nilai oksigen terlarut $<5$ bahwa kondisi tersebut biota dapat hidup dan berkembang pada perairan tersebut. Hal ini sesuai dengan penelitian Augusta dan Evi (2014), jika tidak ada senyawa beracun konsentrasi oksigen minimal $3 \mathrm{mg} / \mathrm{L}$ sudah cukup untuk mendukung kehidupan jasad perairan secara normal. Nilai DO akan semakin menurun seiring dengan kedalamannya, ini disebabkan semakin dalam perairan maka berkurang cahaya matahari yang masuk sehingga proses fotosintesis fitoplankton kurang berjalan dengan baik (Simanjuntak, 2010). Berdasarkan PP No. 51 tahun 2004 menyatakan bahwa nilai standar baku mutu DO untuk kegiatan perikanan sebesar $4 \mathrm{mg} / \mathrm{L}$. Nilai yang didapatkan perairan Koeono dibandingkan dengan PP No. 51 tahun 2004 sudah melebihi ambang batas baku mutu yang telah ditentukan, sehingga kondisi Perairan Koeono masih tergolong bagus.

Salinitas merupakan salah satu parameter penting yang cukup berpengaruh terhadap biota laut, termasuk didalamnya adalah plankton. Peningkatan ataupun penurunan salinitas yang signifikan dapat mempengaruhi kelimpahan plankton (Wenno dan Denisia, 2011). Nilai salinitas yang didapatkan disemua stasiun tidak menunjukkan perbedaan yang signifikan, yaitu 31-34 ppt (Tabel 5 dan Tabel 6). Nilai salinitas tertinggi pada kedalaman yaitu 34 ppt dan terendah 31 ppt. Salinitas yang didapatkan masih dalam kisaran yang baik untuk pertumbuhan plankton.

Kelimpahan zooplankton di stasiun I lebih rendah dan stasiun II tinggi dibandingkan dengan stasiun lainnya hal ini karena nilai arus yang didapatkan pada stasiun I lebih besar yaitu $0,2-03 \mathrm{~m} / \mathrm{s}$ dan stasiun II dengan nilai arus yaitu 0,04-0,08 m/s. kecepatan arus pada stasiun I lebih besar dibandingkan dengan kedua stasiun lainnya sehingga zooplankton yang ditemukan di stasiun I lebih sedikit karena arus membawa zooplankton jauh dari arus yang cepat kelimpahan zooplankton di stasiun II lebih tinggi karena kecepatan arus di stasiun ini lebih kecil dibandingkan kedua stasiun lainnya. Hal ini sesuai dengan pernyataan Nybakken (1998), bahwa arus merupakan faktor utama yang membatasi penyebaran biota dalam perairan. Arus laut dapat membawa larva planktonik jauh dari habitat induknya menuju ke tempat mereka menetap dan berkembang.

Kelimpahan zooplankton mengalami kenaikan dan penurunan dapat disebabkan oleh beberapa faktor seperti pertumbuhan, kematian, distribusi vertikal, migrasi dan perubahan kualitas perairan. Hal ini sejalan dengan pernyataan Wenno dan Denisia (2011), bahwa kelimpahan zooplankton mengalami kenaikan dan penurunan disebabkan oleh faktor masing-masing zooplankton itu sendiri, seperti pertumbuhan, kematian, migrasi yang berbeda, distribusi vertikal dan perubahan kualitas air dari waktu ke waktu. Selain itu adanya pemangsaan ( razing) dari zooplankton karnivora dan predator zooplankton diduga mempengaruhi kelimpahan zooplankton di perairan tersebut.

\section{Kesimpulan}

Berdasarkan hasil penelitian dapat ditarik kesimpulan sebagai berikut:

1. Nilai indeks keanekaragaman ( $\left.\mathrm{H}^{\prime}\right)$ tergolong sedang, sedangkan nilai indeks keseragaman (E') tergolong seimbang. Dan nilai indeks dominansi (D) tergolong sedang yaitu tidak adanya spesises yang mendominasi.

2. Kelimpahan zooplankton di Perairan Koeono tertinggi pada pagi hari (08.0010.00) berada di stasiun II pada kedalamann $10 \mathrm{~m}$ dengan nilai 91 ind./L, terendah pada stasiun I pada kedalaman $0,5 \mathrm{~m}$ dengan nilai 52 ind./L. Dan kelimpahan zooplankton tertinggi pada sore hari (16.00-19.00) berada di stasiun II pada kedalaman $10 \mathrm{~m}$ dengan nilai 176 ind./L, terendah pada stasiun I kedalaman 0,5 dengan nilai 65 ind./L.

\section{Ucapan Terimah Kasih}

Penulis mengucapkan banyak terimah kasih kepada pembimbing dan penguji yang telah memberikan saran dan bimbingan serta teman-teman yang telah membantu baik dalam pengambilan data sampai penyusunan skripsi ini, sehingga dapat terselasaikan dengan baik. 
Daftar Pustaka

APHA. 2005. Standar Methods for Examination of Water and Wastewater. New York.

Augusta T. S. dan Evi S. U. 2014. Analisis Hubungan Kualitas Air Terhadap Komunitas Zooplankton dan Ikan di Danau Hanjalutung. Jurnal Ilmu Hewani Tropika. Vol. 3(2) .

Azis, A. 2019. Hubungan Kualitas Air Terhadap Kelimpahan Zooplankton di Perairan Koeono, Kecamatan Palangga Selatan, Kabupaten Konawe

Selatan (Unpublish).

Bengen. D.G. 2002. Ekosistem dan Sumberdaya Alam Pesisir dan Laut Serta Prinsip Pengelolaannya. Pusat Kajian Sumberdaya Pesisir dan Lautan. Institut Pertanian Bogor (IPB). Bogor.

Botes, L. 2003. Zooplankton. Identification Catalogue (Globallast Monograph Series No. 7). Programme. Saldanha Bay. South Africa.

Dewanti, L. P. P., Putra I. D. N. N. dan Faiqoh E. 2018. Hubungan Kelimpahan Fitoplankton dengan Kelimpahan dan Keanekaragaman Zooplankton di Perairan Pulau Serangan, Bali. Journal Of Marine And Aquatic Sciences. Vol. 4(2) : 324-335.

Fatiqoh, E., Ayu I. P., Subhan B., Syamsuni Y. F., Anggoro A. W. dan Sembiring A. 2015. Variasi Geografik Kelimpahan Zooplankton di Perairan Terganggu, Kepulauan Seribu, Indonesia. Journal of Marine and Aquatic Sciences. Vol. 1: 19-22.

Fitriya. N dan Lukman. M. 2013. Komunitas Zooplankton di Perairan Lamalera dan Laut Sawu, Nusa Tenggara Timur. Jurnal Ilmu dan Teknologi Kelautan Tropis, Vol. 5 (1): 219-227.

Hutagalung, Horas P. 1997. Pengambilan dan Pengawetan Contoh Air Laut : Metoda Analisa Air Laut, Sedimen dan Biota. Buku 2 P3O LIPI. Jakarta.

Iskandar, I., 2003. Komposisi Jenis dan Kelimpahan Zooplankton pada Areal Pertambakan di Desa Lalonggombu Kecamatan Lainea Kabupaten Konawe Selatan. Skripsi Jurusan Fakulats Pertanian Universitas Halu Oleo Kendari.

Junaldi M., Nurliah dan Azhar F. 2018. Struktur Komunitas Zooplankton di
Perairan Kabupaten Lombok Utara, Provinsi Nusa Tenggara Barat. Vol. 18(2) : 159-169.

Medinawati. 2010. Kelimpahan dan Keanekaragaman Plankton di Perairan Laguna Desa Tolongano Kecamanata Benawa Selatan. Media Litbang Sulteng III (2) : $119-123$. 2010.

Minggawati. I. 2014. Komosisi Zooplankton di Perairan Rawa Banjiran Sungai Rungan Kota Palangkaraya. Program Studi Budidaya Perairan Universitas Kristen Palangkaraya. Vol. 39 (2): 8185.

Odum, E. P. 1993. Fundamental of Ecology. Gajahmada University Pres. Yogyakarta.

Patten, P. V. 2010. Dasar-Dasar Ekologi Edisi Ketiga. Yogyakarta. Gadjah Mada University Press.

Puspita, L. P. D., Nyoman, I. D. N. P., dan Faiqoh, E. 2018. Hubungan Kelimpahan dan Keanekaragaman Zooplankton di Perairan Pulau Serangan, Bali. Journal Of Marine and Aquatic Scienses. Vol. 4 (2) : 324-335.

Rahayu, S., Setyawati, T. R. dan Turnip, M. 2013. Struktur Komunitas Zooplankton di Muara Sungai Mempawah Kabupaten Pontianak Berdasarkan Pasang Surut Air Laut. Vol. 2(2): 4955.

Shannon, C. E., W. Winner. 1949. The mathematical Theory of Communication. University of Illinois Press. Urbanan.

Siagian, M. 2012. Jenis dan Keanekaragaman Zooplankton di Waduk. Laboratorium Limnologi. Program Studi Manajemen Sumber Daya Perikanan Fakultas Perikanan Dan Ilmu Kelautan Universitas Riau. Pekanbaru. Bumi Lestari, 7(1): 99-105.

Siro L. O., Salwiyah, dan Nurgayah, W. 2017. Studi Keanekaragaman dan Kelimpahan Zooplankton di Perairan Teluk Staring Desa Wawatu Berdasarkan Kedalaman yang Berbeda di Kecamatan Moramo Utara Kabupaten Konawe Selatan. Fakultas Perikanan dan Ilmu Kelautan, Universitas Halu Oleo. Vol. 4 (2) : 1314. 
Tambaru, R., Muhiddin A. H. dan Malida H. S. 2014. Analisis Perubahan Kepadatan Zooplankton Berdasarkan Kelimpahan Zooplankton pada Berbagai Waktu dan Kedalaman di Perairan Pulau Badi Kabupaten Pangkep. Vol. 24 (3): 4048.

Tawuning, D., Rahayu, S. dan Triastinurmiatiningsih. 2018. Plankton sebagai Bioindikator Kualitas Air di Sungai Cikaniki, Kecamatan Manggung, Kabupaten Bogor. Vol. 1(1). 66-98

Wardoyo, S.T. 1997. Pengelolaan Pencemaran dan Kualitas Air Wilayah Pesisir, Pusat Kajian Sumberdaya Pesisir dan Laut Lembaga Penelitian Institute Pertanian Bogor. Bogor.

Wati, M., Irawati N. dan Indrayani. 2018. Pola Migrasi Vertikal Harian Zooplankton pada Berbagai Kedalaman di Perairan Pulau Bungkutoko Kecamatan Abeli. Jurnal Manajemen Sumber Daya Perairan. Vol. 4(1): 61-63.

Wenno, Y., dan Denisia A. W. 2011. Hubungan Antara Beberapa Faktor Lingkungan dengan Kelimpahan Zooplankton di Perairan Teluk Baguala, Ambon. Jurnal Perikanan dan Kelautan. Vol.2 (7).

Wiadyana, N.,N. 1997. Variasi Kelimpahan Zooplankton di Teluk Kao. Oseanologi dan Limnology di Indonesia. 53-62 hal.

Yamaji, E. E. 1966. Ilustration Of The Marine Plankton Of Japan. Hoikusha Osaka Japan. 